\title{
Isolation of Enteric Viruses from Sewage of a Sewage Treatment Plant
}

\author{
Naoto TANI, Tsuneki INOUE, Satoshi YOSHIDA, Mamoru NAKANO, \\ Koh SHIMAMOTO and Yasuji NISHII \\ Nara Prefectural Institute of Public Health, Ohmori-cho 57-6 Nara, Japan 630 \\ Key Words: Enteric virus, Epidemic, Isolation, Sewage
}

\begin{abstract}
Isolation of enteric viruses from sewage of a sewage treatment plant in Nara Prefecture was carried out during one-year from June 1984 to May 1985. Both supernatant and sediment of the sewage samples were subjected to virus isolation. Viruses were isolated almost similarly from the supernatants and the sediments.

Poliovirus, echovirus, coxsackievirus, adenovirus and reovirus were found in the sewage. Polioviruses were isolated during the periods which coincided with those of vaccine administration, and the group B coxsackieviruses were frequently isolated all year round. Among the group B coxsackieviruses isolated type B2, B4 and B5 viruses were isolated successively for a long period, suggesting that these type viruses caused epidemics. The incidences of antibodies against the group B coxsackieviruses in the sera collected in this study area supported that these types of viruses caused epidemics. Futhermore, we observed that the epidemic of type B4 which virus occurred in 1984 though this type was isolated successively for a long period in 1983.
\end{abstract}

\section{Introduction}

Enteric viruses are the most important viruses having infectivity for humans known to be present in water $^{1)}$. These viruses are transmissible to humans via the oral route, grown in the throat and the intestinal walls, and are excreted in the feces ${ }^{2)}$. They may enter the environmental water and present a health hazard to humans. It is important to survey the viral pollution of the environmental water from the viewpoint of public health. Many reports on isolation of viruses from environmental water have been made, however, little information on the relationship between virus isolated and virus causing epidemic have been obtained.

Therefore, we attempted to isolate enteric viruses from the sewage of a sewage treatment plant in Nara Prefecture for a one-year and examine the epidemics of viruses isolated.

\section{Materials and Methods}

\section{Sewage samples}

Samples (one liter) of sewage were collected every week for one year (May 1984-June 1985) at a sewage treatment plant in Nara Prefecture. The sewage samples were centrifuged at $3000 \mathrm{rpm}$ for $20 \mathrm{~min}$ at $4^{\circ} \mathrm{C}$. The supernatants were concentrated about 100 -fold by polyethylene glycol 6000 hydroextraction by to the method of Gibbs et $\mathrm{al}^{3)}$. The concentrated supernatants were centrifuged at $15000 \mathrm{rpm}$ at $4^{\circ} \mathrm{C}$ and were subjected to the virus isolation after addition of penicillin and streptomycin to a final concentration of 1 $\mathrm{mg} / \mathrm{ml}$ and $5 \mathrm{mg} / \mathrm{ml}$, respectively. The sediments obtained were suspended in $3 \%$ beef extract solution (10

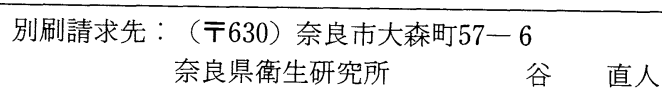


$\mathrm{ml}$, Difco), shaken vigorously for $10 \mathrm{~min}$ and allowed to stand at $4^{\circ} \mathrm{C}$ overnight. Then, the suspensions were centrifuged at $3000 \mathrm{rpm}$ for $20 \mathrm{~min}$ and then, at $15000 \mathrm{rpm}$ for $30 \mathrm{~min}$ at $4^{\circ} \mathrm{C}$. The supernatants obtained were subjected to the virus isolation after addition of penicilline and streptomycin.

\section{Cell culture}

FL cells, Hep-2 cells and Vero cells which were purchased from Dainippon Seiyaku Co. were used for the virus isolation. These cells were grown and maintained in Eagle minimum essential medium (MEM/ Nissui Seiyaku, Japan) with $10 \%$ or $2 \%$ fetal calf serum (Gibco), respectively.

\section{Virus isolation}

Aliquots in amounts of $0.2 \mathrm{ml}$ of the samples prepared as described above were inoculated onto monolayer cells prepared in culture tubes and incubated at $36^{\circ} \mathrm{C}$ for $1 \mathrm{~h}$. After the inoculum was descarded, Eagle MEM containing $2 \%$ fetal calf serum $(1 \mathrm{ml})$ was added to each tube. Then, the tubes were incubated at $36^{\circ} \mathrm{C}$ and observed daily for viral cytopathic effect (CPE) for 7 days. A secondary passage was performed by inoculating new culture tubes with $0.2 \mathrm{ml}$ of the harvest of the culture fluid on the 7 th day of inoculation and CPE was also observed for 7 days. A third passage was carried out in the same manner as above. A suspension was considered to be virus free if there was no observable CPE in the culture tubes for not less than 21 days after the first inoculation.

\section{Virus identification}

Cultures showing CPE were frozen and thawed, and the viruses were subsequently identified as follows: Virus isolates in culture tubes were grouped according to the nature of CPE and the results of hemagglutinating assay using human erythrocytes $(0$ type). Poliovirus, the group B coxsackievirus and echovirus were identified by the neutralization test ${ }^{4)}$ using Schmidt pooled sera. Adenovirus was also identified by the neutralization using type-specific rabbit antisera to adenoviruses. These sera were kindly supplied from the National Institute of Health of Japan. Reovirus was identified by the hemagglutinationinhibition test in microtiter plates ${ }^{5}$.

\section{Incidence of antibodies against the group B coxsackieviruses}

The incidence of antibodies against prototype strains of the group B coxsackieviruses in the sera (1:4

Fig. 1 Isolation of enteric viruses from sewage. Samples of sewage were collected for a year (June 1984-May 1985) and the supernatants $(0)$ and the sediments $(+)$ of the samples were sujected to virus isolation.

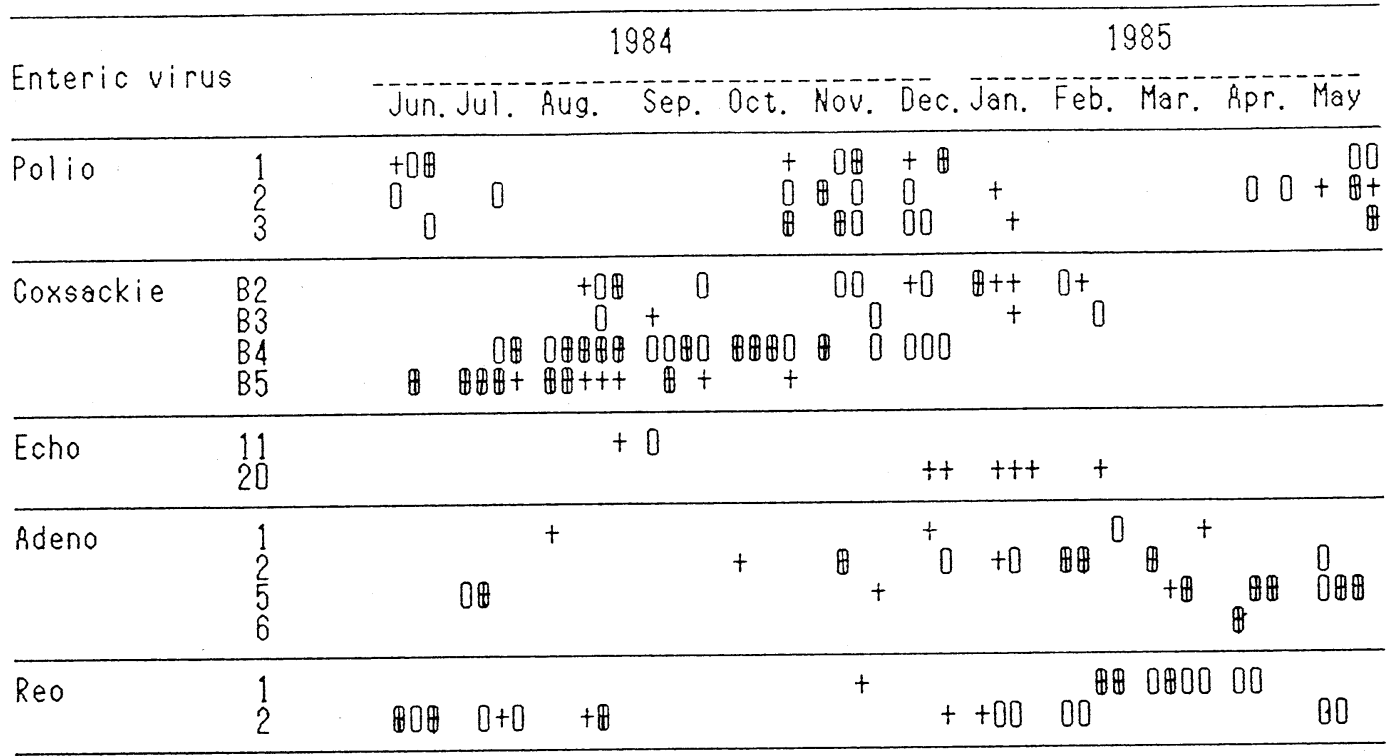


Fig. 2 Age distribution of neutralizing antibody against the group B coxsackieviruses (1:4 dilutions).

$\longrightarrow 1984, \bigcirc \multimap 01985, \star \mathrm{p}<0.05, \star \star \mathrm{p}<0.005$

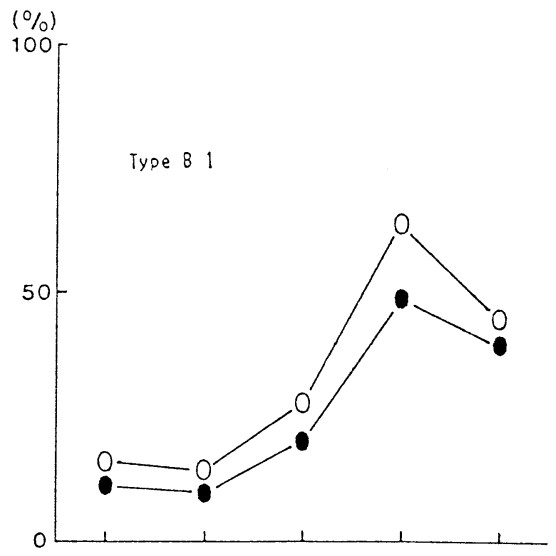

Type 82
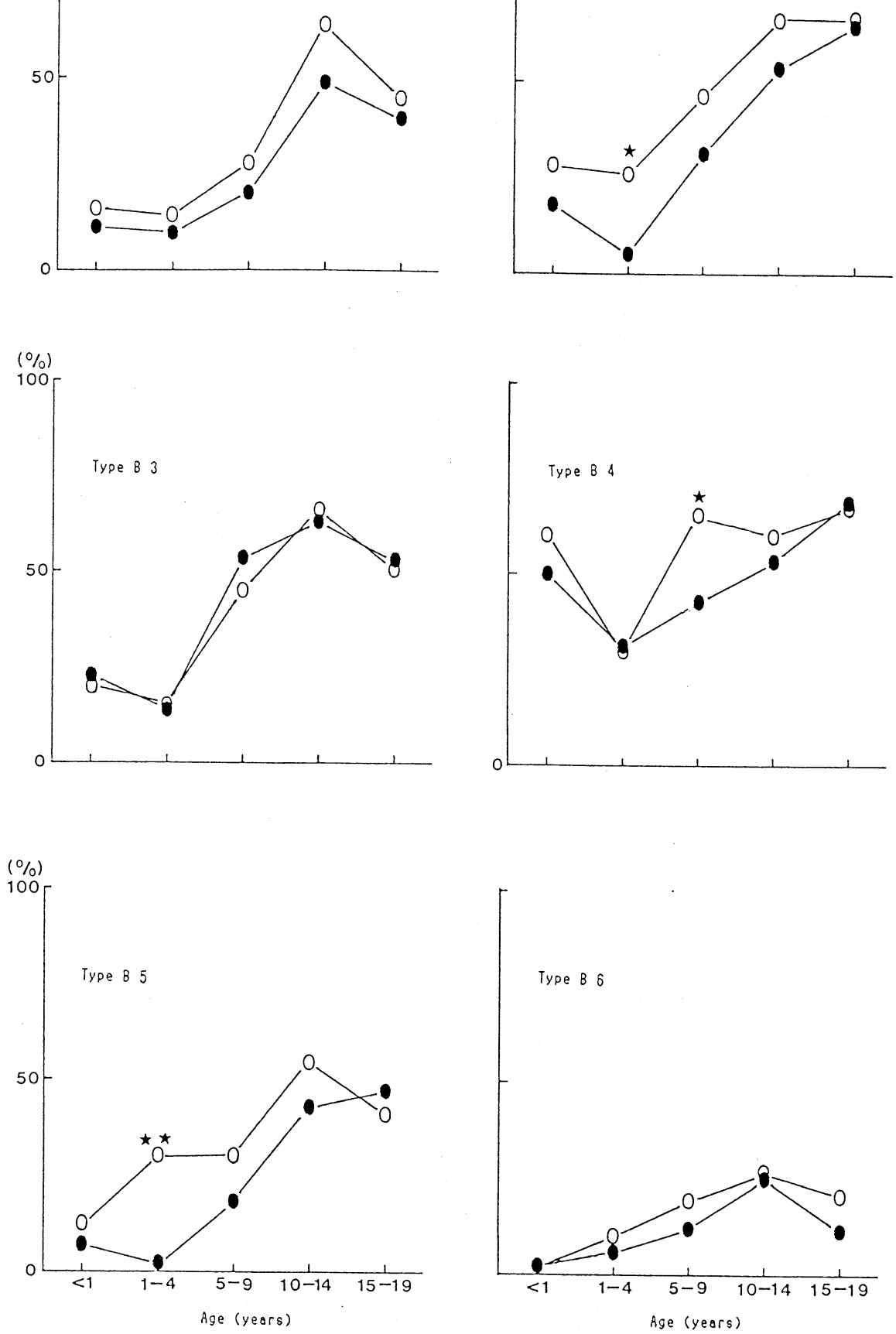
dilutions) were examined by the neutralization test using HeLa cells. Sera were collected at a hospital in this study area. The numbers of the sera samples collected were as follows: 246 during February-April 1984 (44/aged 0 to 1,51 /aged 1 to 4, 49/aged 5 to 9 , 49/aged 10 to 14 and 53/aged 15 to 19) and 253 during March-May 1985 (50/aged 0 to 1, 50/aged 1 to 4,54/aged 5 to 9, 50/aged 10 to 14 and 49/aged 15 to 19).

\section{Results}

\section{Virus isolation from sewage}

The results of virus isolation from the sewage are shown in Fig. 1. Of 47, 46 sewage samples contained viruses in the supernatants or the sediments. The numbers of virus strains isolated from the supernatants and the sediments were 99 and 84 , respectively. The total number of virus strains isolated from the sewage samples was 138 .

Polioviruses were isolated during the periods coincided with those of vaccine administration (April and October 1984). Echoviruses were isolated during summer and winter. Adeno- and reoviruses were isolated through a year. Among the viruses isolated the group B coxsackieviruses was most frequently isolated at a maximum in the summer. Among the group B coxsackieviruses type B2, B4 and B5 viruses were isolated successively for a long period, suggesting that viruses of these types had caused epidemics.

\section{Incidence of antibodies against the group B coxsackieviruses}

Age distribution of neutralization antibody against the group B coxsakieviruses is shown in Fig. 2. In type B2, the antibody incidence of aged $1-4$ were significantly different in 1984 and $1985(\mathrm{p}<0.05)$. Significant differences in the antibody incidences of 1984 and 1985 were also observed in type B4/aged 5-9 $(\mathrm{p}<0.05)$ and type B5/aged $1-4(\mathrm{p}<0.005)$. These results showed that type B2, B4 and B5 viruses invaded in this study area, spread widely and epidemic of type B2, B4 and B5 viruses occurred during this study period, mainly in children of $1-4,5-9$ and $1-4$ year olds, respectively.

\section{Discussion}

We have been surveyed enteric viruses in water since $1982^{6 \sim 8)}$. In our survey polio, adeno and reovirus were isolated from water almost similary every year. On the other hand, the types of the group B coxsackieviruses which were isolated successively for a long period changed from year to year; type B3 in 1982, type B4 in 1983, and type B2, B4 and B5 in this study period. Yabuuchi et al. reported that a type of coxsackieviruses $B$ was isolated for a brief period from sewage in the previous year when this type of virus caused epidemic ${ }^{9}$. We obtained similar observations in our previous studies. In this study the interesting fact was found that type B4 of coxsakeivirus caused an epidemic in 1984, though this type was isolated successively for a long period in 1983. This indicates the possibility that coxsackieviruses which are isolated not only for a brief period but also for a long period will cause epidemics the next year. At present, it is difficult to prognosticate a virus epidemic. Therefore, it is important to survey virus in water and accumulate valuable data about virus pollution in the community from the viewpoint of public health.

Polioviruses were isolated during the periods coincided with those of the live vaccine administration. Similar observations in Tokyo were reported by Hayashi et al. ${ }^{10)}$. In Japan, it is thought that wild strains of polioviruses do not exist. Indeed, Kuroda et al. ${ }^{11)}$ and $\mathrm{Ohtsu}^{12)}$ reported that all the polioviruses isolated by their groups were identified to be vaccine derived strains, not wild strains. Therefore, polioviruses isolated in this study seemed to be vaccine derived.

Much information about enteric virus in water have been obtained, however, most of these dealed with enteric virus only in the supernatant of water samples. It is known that many viruses exist in particle bound form in water ${ }^{13,14)}$. In this study we also isolated many viruses from the sediments as well as from the supernatant of sewage samples by a simple procedure. For a virus survey in water, therefore, a 
combined use of both supernatant and sediment of water sample is desirable.

\section{References}

1) Geldreich, E.E.: Water-borne pathogens, p. 207-235 in Mitchell, R. (eds), Water pollution microbiology, Wiley and Sons, New, York. 1972.

2) Norman, R.G., Eleanor, J.B. \& Fakhry, A.: Enteroviruses in human disease. Prog. Med. Virol. 24: 114-157, 1978.

3) Gibbs, T. \& Cliver, O.: Methods for detecting minimal contamination with reovirus. Hith. Lab. Sci. 2: 81-88, 1971.

4) Members of the bational Institute of Health, Japan (eds), 1982. Experimental virology, Maruzen, Tokyo.

5) Rosen, L.: Serologic grouping of reovirus by hemagglutination inhibition. Am. J. Hyg. 7: 242-249, 1960.

6) Tani, N., Inoue, T., Yoshida, S., Shimamoto, K., Nishii, Y \& Itano, T.: Detection of enteric viruses from sewage. Jpn. J. Public Health 31: 379-383, 1984.

7) Tani, N., Inoue, T., Yoshida, S., Adachi, O., Nakano, M., Shimamoto, K., Nishii, Y. \& Itano, T.: Isolation of enteric viruses from river water. Koushu Eisei. 50: 345-348, 1986.

8) Tani, N., Inoue, T., Yoshida, S., Nakano, M., Shimamoto, K. \& Nishii, Y.: Isolation of enteric viruses from sewage and human samples. Clin. Virol. 15: 75-79, 1987.

9) Yabuuchi, K., Yano, K., Shibata, T., Hayashi, Y. and Iwasaki, K.: Incidence of enteroviruses in sewage taken from nine sewage treatment plants in Tokyo. Ann. Rep. Tokyo Metr. Res. Lab. Public Health. 31: 36-39, 1980.

10) Hayashi, Y., Yano, K., Yabuuchi, K., Watanabe, T., Ishihara, Y., Ohkubo, S. \& Inyaku, F.: Enteric virus surveillance in Tokyo. Virus isolation from patients and sewage samples. Ann. Rep. Tokyo Metr. Res. Lab. Public Health. 35: 55-60, 1984.

11) Kuroda, K., Murakami, T. \& Nagai, M.: Detection of viruses in river water.Jpn. J. Public Health. 28: 481-486, 1981.

12) Otsu, K. \& Yamazaki, K.: Studies on the characteristics of polioviruses isolated from sewage. Proc. Osaka Pref. Inst. Public Health. 16: 5-7, 1978.

13) Lund, E.: The effect of pretreatments on the virus contents of sewage. Water Res. 7: 873-879, 1973.

14) Wellings, F.M., Lewis, A.L., Mountain, C.W.: Demonstration of solid-associated viruses in wastewater and sludge. Appl. Environ. Microbiol. 31: 354-358, 1976.

\section{下水処理場の下水からの腸管系ウイルスの分離}

\begin{tabular}{lrrrrr}
\multicolumn{4}{c}{ 奈良県衛生研究所 } & & \\
谷 & 直人 & 井上 & 凡己 & 吉田 & 哲 \\
中野 & 守 & 島本 & 剛 & 西井 & 保司
\end{tabular}

(昭和 62 年 12 月 24 日受付)

(昭和63年 2 月 9 日受理)

1 年間, 奈良県内の下水処理場に扔いて, 腸管 系ウイルスの分離を行った。沈査検体でも上清検 体とほぼ同じ分離株数であった。 したがって水中 のウイルス監視にあたっては，両者の併用がよい と思われた。

下水から分離されたウイルスは，ポリオ，コク サッキーB群; エコー，アデノ执よびレオウイル
スであり，コクサッキーB 群ウイルスは最も多く 分離された。 その中でも B2，B4および $\mathrm{B} 5$ 型が長 期間しかも連続的に分離されたことからこれらの ウイルスの流行があったことが推測された。さら に血清疫学的にみても，1〜4歳を中心に流行し たことがうかがわれた。をた B4型は前年(1983年) にも長期間分離されていた。 